\title{
Molecular Characterization of Low-Density Polyethene (LDPE) Degrading Bacteria and Fungi from Dandora Dumpsite, Nairobi, Kenya
}

\author{
Christabel Ndahebwa Muhonja $\mathbb{D}^{1},{ }^{1}$ Gabriel Magoma, ${ }^{1}$ Mabel Imbuga, ${ }^{2}$ \\ and Huxley Mae Makonde ${ }^{3}$ \\ ${ }^{1}$ Pan African University of Science and Technology, P.O. Box 62000-00200, Nairobi, Kenya \\ ${ }^{2}$ Jomo Kenyatta University of Agriculture and Technology, P. O. Box 62000-00200, Nairobi, Kenya \\ ${ }^{3}$ Department of Pure \& Applied Sciences, Technical University of Mombasa, P. O. Box 90420-80100, Mombasa, Kenya
}

Correspondence should be addressed to Christabel Ndahebwa Muhonja; muhosh@gmail.com

Received 26 July 2018; Revised 22 September 2018; Accepted 2 October 2018; Published 3 December 2018

Academic Editor: Barbara H. Iglewski

Copyright (c) 2018 Christabel Ndahebwa Muhonja et al. This is an open access article distributed under the Creative Commons Attribution License, which permits unrestricted use, distribution, and reproduction in any medium, provided the original work is properly cited.

\begin{abstract}
This study aimed at molecular and biochemical characterization of low-density polyethene (LDPE) degrading fungi and bacteria from Dandora dumpsite, Nairobi. Twenty bacterial and 10 fungal isolates were identified using 16S rDNA and 18S rDNA sequences for bacteria and fungi, respectively. The highest fungal degradation was attributed to Aspergillus oryzae strain A5,1 while the highest bacterial degradation was attributed to Bacillus cereus strain A5,a and Brevibacillus borstelensis strain B2,2, respectively. Isolates were screened for their ability to produce extracellular laccase and esterase; Aspergillus fumigatus strain B2,2 exhibited the highest presence of laccase $(15.67 \mathrm{~mm})$ while Aspergillus oryzae strain A5,1 exhibited the highest presence of esterase $(14.33 \mathrm{~mm})$. Alkane hydroxylase-encoding genes were screened for using primer AlkB 1 which amplified the fragment of size $870 \mathrm{bp}$. Four bacterial samples were positive for the gene. Optimum growth temperature of the fungal isolates was $30^{\circ} \mathrm{C}$. The possession of laccase, esterase, and alkane hydroxylase activities is suggested as key molecular basis for LDPE degrading capacity. Knowledge of optimum growth conditions will serve to better utilize microbes in the bioremediation of LDPE. The application of Aspergillus oryzae strain A5,1 and Bacillus cereus strain A5,a in polyethene degradation is a promising option in this kind of bioremediation as they exhibited significantly high levels of biodegradation. Further investigation of more alkane degrading genes in biodegrading microbes will inform the choice of the right microbial consortia for bioaugmentation strategies.
\end{abstract}

\section{Introduction}

Low-density polyethene is a major cause of environmental pollution due to its high tensile strength, lightness, resistance to water, and microbial attack. The consumption of plastics in the country has increased to 4,000 tons per annum of polyethene bags which together with hard plastics end up scattered in the environment creating "the plastics menace" [1]. Through the National Environmental Management Authority (NEMA), Kenya has embraced the 3Rs, reduce, reuse, and recycle, concept of solid waste management [2] and most recently the ban on the use of polyethene carrier bags but this has not addressed the problem of polyethene which remains scattered in the environment [3].

Biodegradation is the decomposition of substances through microbial activity and is a complex process which involves the following steps [4]: biodeterioration, depolymerization, assimilation, and mineralization. Bacteria and fungi of various genera have been implicated previously in the biodegradation of polyethene albeit the low rates. Acinetobacter sp. was found capable of utilizing $n$-alkanes of chain length $\mathrm{C} 10-\mathrm{C} 40$ as a sole source of carbon as reported by [5]. Bacterial genera, namely, Pseudomonas, Acinetobacter, Brevibacillus, Rhodococcus, and Micrococcus $[6,7,1]$, respectively, isolated from different sources proved to be the 
potential organisms for polyethene degradation. Fungal genera, Gliocladium, Cunninghamella, Penicillium, Aspergillus, Fusarium, Mucor, and Mortierella, from soil [1] were proven to have the potential to degrade polyethene after analysis of degradation through various methods.

Plastic biodegradation as a result of the activity of certain enzymes causes cleavage of the polymer chains into monomers and oligomers. Enzymatically broken down plastic is further absorbed by the microbial cell to be metabolized. Aerobic breakdown produces carbon dioxide and water. The involvement of enzymes in microbial biodegradation of polyethene has been investigated, and enzymes such as laccases and esterases have been confirmed to play a role in this process either directly or indirectly [8]. The production of enzyme laccase in the presence of polyethene as the sole carbon source is a clear indication that laccase has a role in breaking down some of the intermediary products produced during this process. In this study, molecular characterization of bacteria and fungi that had been confirmed to degrade polyethene was done as well as assessment of optimum $\mathrm{pH}$, temperature, and sodium chloride concentration at which they can thrive. Presence of AlkB genes that encode alkane hydroxylases known to hydrolyze alkanes was also investigated.

\section{Materials and Methods}

2.1. Bacterial DNA Extraction. Total genomic DNA was isolated from the bacterial pure cultures grown to the late exponential phase by means of a standard protocol [9] as follows: $1.5 \mathrm{ml}$ of the overnight bacterial culture (grown in the LB medium) was transferred to a $1.5 \mathrm{ml}$ Eppendorf tube and centrifuged at $13000 \mathrm{rpm}$ for $1 \mathrm{~min}$ to pellet the cells. The supernatant was discarded. The cell pellet was suspended in $600 \mu \mathrm{l}$ TE buffer and centrifuged at $13000 \mathrm{rpm}$ and the supernatant discarded. The cell pellet was resuspended in $200 \mu \mathrm{l}$ TE buffer, and the following were added: $5 \mu \mathrm{l}$ lysozyme $(20 \mathrm{mg} / \mathrm{ml}), 5 \mu \mathrm{l}$ RNAnase $(20 \mathrm{mg} / \mathrm{ml})$, and $10 \mu \mathrm{l}$ proteinase $\mathrm{K}(20 \mathrm{mg} / \mathrm{ml})$ followed by overnight incubation at $37^{\circ} \mathrm{C}$. In the next morning, the temperature was adjusted to $56^{\circ} \mathrm{C}$ for one $\mathrm{hr}$ and an equal volume of phenol/chloroform $(1: 1)$ was added and mixed well by inverting the tube until the phases were completely mixed. Spinning was done at $13000 \mathrm{rpm}$ for $15 \mathrm{~min}$ at room temperature. The upper aqueous phase was carefully transferred to a new tube by using $1 \mathrm{ml}$ pipette. This step was repeated twice to ensure all protein had been removed. An equal volume of chloroform and isoamyl (24:1) was added to the aqueous layer and centrifuged at $13000 \mathrm{rpm}$ for $15 \mathrm{~min}$. The aqueous layer was removed into a new tube. This step was also repeated to ensure all phenol is removed. An equal volume of isopropanol was added and stored overnight at $-20^{\circ} \mathrm{C}$. The samples were then defrosted and centrifuged at $4^{\circ} \mathrm{C}$ for $30 \mathrm{~min}$ to pellet the DNA. The pellet was washed in $70 \%$ ethanol and centrifuged at $13000 \mathrm{rpm}$ for $5 \mathrm{~min}$, and then, the ethanol was carefully pipetted out. The pellet was air dried on the bench for $20 \mathrm{~min}$, and the isolated genomic DNA was viewed on a $1 \%$ agarose gel.
2.2. Bacterial DNA Amplification and Sequencing. Amplification of the $5^{\prime}$ end of the 16S rDNA gene was performed with universal primers (forward primer $(8-\mathrm{F}) 5^{\prime}$ AGAGTTTGATYMTGGCTCAG-3') and reverse primer ((1942R)5'-GGTTACCTTGTTACGACTT-3’) [10]. The PCR was performed on a GeneAmp PCR system 9600 (Applied Biosystems), using $1 \mu \mathrm{l}$ Taq Polymerase (Applied Biosystems), $1 \mu \mathrm{l}$ each of $10 \mathrm{pM}$ concentrations of forward and reverse primers, $27 \mu \mathrm{l}$ sterile deionized water, $8 \mu \mathrm{l}$ PCR buffer containing dNTPs and $\mathrm{MgCl}_{2}$, and $2 \mu \mathrm{l}$ DNA template, for a total reaction volume of $40 \mu \mathrm{l}$. The cycling program used was as follows: 1 cycle of $94^{\circ} \mathrm{C}$ for $5 \mathrm{~min} ; 30$ cycles of $94^{\circ} \mathrm{C}$ for $30 \mathrm{sec}, 55^{\circ} \mathrm{C}$ for $30 \mathrm{sec}$, and $72^{\circ} \mathrm{C}$ for $1.5 \mathrm{~min}$; and a final extension of $72^{\circ} \mathrm{C}$ for $10 \mathrm{~min}$. The PCR products were visualized through electrophoresis on a $1 \%$ agarose gel with ethidium bromide added directly. The $1.5 \mathrm{kbp}$ products were subjected to Sanger dideoxy sequencing using the forward primer and reverse primers at Macrogen DNA, Inc. (Netherlands). Sequence files were edited using Chromas version 2.6.2 and compared to the GenBank nucleotide database using the basic local alignment search tool (BLAST). Phylogenetic relationships were inferred using Mega 7 [11], and maximumlikelihood algorithms were available in Phylip. Maximum likelihood and parsimony-derived trees were bootstrapped using PHYML [12, 13].

2.3. Fungal DNA Extraction. Fungal DNA extraction protocol reported by Gontia-mishra et al. [14] was used. Fungal mycelia were grown for 7 days at $55^{\circ} \mathrm{C}$ on potato dextrose agar. Mycelia were frozen in liquid nitrogen and ground to a fine powder using a mortar and pestle. The powder was transferred into $2 \mathrm{ml}$ tubes, and $600 \mu \mathrm{l}$ of preheated extraction buffer was added. The contents were incubated in a water bath at $65^{\circ} \mathrm{C}$ for 30 minutes with mixing after every 10 minutes. $270 \mu \mathrm{l}$ volume of $5 \mathrm{M}$ potassium acetate was added and centrifuged at $13000 \mathrm{rpm}$ for 10 minutes. $700 \mu \mathrm{L}$ of the supernatant was transferred into clean tubes, and $5 \mu \mathrm{L}$ RNASE $(10 \mathrm{mg}$ ) was added and then incubated for 30 minutes at $37^{\circ} \mathrm{C}$. Chloroform and iso-amyl alcohol was prepared in the ratio of $24: 1$, and an equal volume was added to the mixture. $600 \mu \mathrm{L}$ of supernatant was pipetted into clean tubes. DNA was precipitated by adding a tenth of the volume of $3 \mathrm{M}$ potassium acetate and two thirds of the volume of isopropanol. This was incubated at $-20^{\circ} \mathrm{C}$ for 30 minutes then centrifuged at $13000 \mathrm{rpm}$ for 10 minutes. The pellet was washed using $70 \%$ ethanol followed by 10 minutes of centrifuging, and then, the DNA was eluted in $50 \mu \mathrm{L}$ of RNASE-free water and stored at $-20^{\circ} \mathrm{C}$.

2.4. Fungal DNA Amplification and Sequencing. PCR was performed on a GeneAmp PCR system 9600 (Applied Biosystems), using $1 \mu \mathrm{l}$ Taq Polymerase (Applied Biosystems), $1 \mu$ l each of $10 \mathrm{pM}$ of forward and reverse primers, $27 \mu \mathrm{l}$ deionized water, $8 \mu \mathrm{l}$ PCR buffer containing dNTPs and $\mathrm{MgCl}_{2}$, and $2 \mu \mathrm{lDNA}$ template, for a total reaction volume of $40 \mu \mathrm{l}$. The cycling program used was as follows: 1 cycle of $95^{\circ} \mathrm{C}$ for $5 \mathrm{~min} ; 35$ cycles of $95^{\circ} \mathrm{C}$ for $30 \mathrm{sec}, 60^{\circ} \mathrm{C}$ for $45 \mathrm{sec}$, and $72^{\circ} \mathrm{C}$ for $40 \mathrm{sec}$; and a final extension of $72^{\circ} \mathrm{C}$ for $5 \mathrm{~min}$. 
Primer pair F-566:5'-CAGCAGCCGCGGTAATTCC-3' and for R- 1200:5' -CCCGTGTTGAGTCAAATTAAGC-3' which amplify on average a $650 \mathrm{bp}$ long fragment from the V4 and V5 regions were used [15]. The PCR products were visualized through electrophoresis on a $1 \%$ agarose gel with ethidium bromide added directly. The products were subjected to Sanger dideoxy sequencing by Macrogen, Inc. (Netherlands). SeqMan Pro was used to assemble both the forward and reverse sequence files [16]. The sequences obtained were compared against the sequences available in the NCBI database using the basic local alignment tool (BLAST). The $18 \mathrm{~S}$ rDNA gene sequences obtained in current study, together with those of the closest neighbor strains, were aligned using ClustaX version 2.1. Phylogenetic relationships were inferred using Mega 7 [11], and maximumlikelihood algorithms were available in Phylip. Maximum likelihood and parsimony-derived trees were bootstrapped using PHYML [12, 13].

2.5. Screening for Production of Enzymes. Bacterial isolates were screened for their ability to produce extracellular enzymes, i.e., laccases and esterases. The ability of the isolates to utilize substrates such as lignin and tween 20 exhibited their ability to produce the respective enzymes [17].

2.5.1. Determination of Presence of Enzyme Laccase. The media for selection of lignin-modifying fungi were prepared by the use of plain agar and minimal salt media with the incorporation of lignin (to encourage selection of lygninolytic fungi) and Guaiacol, which acts as a colorimetric indicator of the lignin-modifying enzymes laccase or peroxidases. All chemicals were obtained from Sigma Chemical Co., St. Louis. The presence of a reddish coloration after 3-5 days of incubation was an indication of laccase activity. The laccase assay per 1 liter: $400 \mu \mathrm{l}$ Guaiacol, agar $15 \mathrm{~g}, 2 \mathrm{~g}$ malt extract, $0.5 \mathrm{~g} \mathrm{KH}_{2} \mathrm{PO}_{4}, 0.001 \mathrm{~g} \mathrm{ZnSO}_{4}, 0.4 \mathrm{~g} \mathrm{~K}_{2} \mathrm{HPO}_{4}, 0.02 \mathrm{~g}$ $\mathrm{FeSO}_{4}$, and $0.2 \mathrm{~g} \mathrm{MgSO}_{4}, 0.5 \mathrm{~g} \mathrm{KH}_{2} \mathrm{PO}_{4}, 0.1 \mathrm{~g} \mathrm{NH}_{4} \mathrm{NO}_{3}, 0.1 \mathrm{~g}$ $\mathrm{KCl}, 5 \mathrm{ml} \mathrm{KOH}, 0.25 \mathrm{~g}$ chloramphenicol, forming a reddish colored zone as a positive result.

2.5.2. Determination of Presence of Enzyme Esterase. The isolates were cultured on basal media $\left(1 \% \mathrm{KH}_{2} \mathrm{PO}_{4}, 0.01 \%\right.$ $\mathrm{MgSO}_{4} \cdot 7 \mathrm{H}_{2} \mathrm{O}, 0.005 \% \mathrm{CaCl}_{2} \cdot 2 \mathrm{H}_{2} \mathrm{O}, 4 \% \mathrm{NaCl}$, and $1 \%$ $\mathrm{Na}_{2} \mathrm{CO}_{3}$ ) supplemented with $1 \%$ tween 20 (domestic grade) as the sole carbon source. The medium was then thereafter inoculated by the spotting of isolates per plate and incubated for at least 48 hours at $37^{\circ} \mathrm{C}$ for bacteria and at $28^{\circ} \mathrm{C}$ for $3-5$ days for fungal isolates. The media were observed for zones of precipitation of calcium crystals around each isolate. Positive isolates for esterases production were indicated by the precipitation of calcium crystals around the colonies.

2.5.3. Screening for Genes Producing Alkane-Degrading Enzymes. Amplification was done using the sets of AlkB primers [18] shown in Table 1. The PCR was performed on a GeneAmp PCR system 9600 (Applied Biosystems) using Taq DNA polymerase. A total of 30 cycles of amplification was performed with template DNA denaturation at $94^{\circ} \mathrm{C}$ for $1 \mathrm{~min}$, primer annealing at $40^{\circ} \mathrm{C}$ for $1 \mathrm{~min}$, and primer extension at $72^{\circ} \mathrm{C}$ for $2 \mathrm{~min}$ [19]. The PCR products were visualized through electrophoresis on a $1 \%$ agarose gel with $2 \mu \mathrm{l}$ ethidium bromide added directly.

2.6. Effect of Temperature on Growth of Fungal Isolates. Potato dextrose agar augmented with $250 \mathrm{mg} / \mathrm{ml}$ ampicillin to inhibit bacterial growth at pH 7.0 was prepared, sterilized, and dispensed in sterile Petri dishes. Each plate was inoculated with one fungal isolate and incubated at temperatures 20,30 , and $40^{\circ} \mathrm{C}$. Growth of isolates was checked after 4 days of incubation. The level of growth was scored using the colony diameter, whereby $0 \mathrm{~mm}$ indicated no growth, 1$2 \mathrm{~mm}$ indicated minimal growth, 3-4 mm indicated average growth, and $5-7 \mathrm{~mm}$ indicated satisfactory growth while $8-10 \mathrm{~mm}$ indicated excellent growth.

\section{Results and Discussion}

3.1. Phylogenetic Relatedness of Low-Density Polyethene Degrading Fungal Isolates. Amplification of fungal $18 \mathrm{~S}$ rDNA using $1200 \mathrm{R}$ and $566 \mathrm{~F}$ universal primers yielded the expected band size of approximately $640 \mathrm{bps}$ from the PCR products of the amplified samples (Figure 1). These products were purified, sequenced, and analyzed. The results were used to obtain accession numbers from the NCBI GenBank. The analyzed sequences were aligned with those of the closest neighbors using ClustalX version 2.1. Phylogenetic relationships were inferred from phylogenetic comparison of the $18 \mathrm{~S}$ rDNA sequences using Mega 7 and maximumlikelihood algorithms to generate the phylogenetic tree (Figure 2) which shows the phylogenetic relationships among the various Aspergillus species. The tree displays four clades in which the isolates have been clustered. From our previous study [20], Aspergillus oryzae (MG779508) resulted in a weight loss of $36.4 \pm 5.53 \%$ which was the highest. Aspergillus oryzae is a promising biodegrader of polyethene as it was able to degrade $30 \%$ of polyethene in 200 days [21] in addition to formation of microcracks and increased embrittlement of the LDPE surface upon SEM analysis. In a study done using untreated LDPE incubated with $A$. oryzae, $5 \%$ weight loss was recorded compared with control (untreated and unexposed). Aspergillus fumigatus strain B2,2 (MG779513) recorded a weight reduction of $24 \pm 3.26 \%$ which was the second highest in our previous study [20]. Aspergillus fumigatus is also among the species that have been investigated for their ability to degrade polyethene and other polymers. In a study, three fungal species were investigated for their ability to degrade polyethene, and $A$. fumigatus was the best degrader compared to A. terreus and F. solani following an analysis of the LDPE surface by SEM and FTIR [22]. Other fungi implicated in this study included Aspergillus nidulans, A. flavus, A. terreus, and A. neoflavipes which resulted in weight loss of the LDPE sheets. Use of weight reduction as a measure of the extent of polyethene biodegradation has been widely accepted and used by many authors [23]. 
TABLE 1: Primers for AlkB genes encoding depolymerases responsible for alkane degradation [18].

\begin{tabular}{lcc}
\hline Primers and position & PCR product & Reference \\
\hline alkB 1 set 1 & 870 bp & Kok et al. \\
$825^{\prime}$-TGGCCGGCTACTCCGATGATCGGAATCTGG-3' 111 & & \\
$9515^{\prime}$-CGCGTGGTGATCCGAGTGCCGCTGAAGGTG-3' 922 & 718 bp & Stover et al \\
\hline alkB 1 set 2 & & 749 bp \\
$1345^{\prime}$-CATTTCCCTGGTGATTG-3' 151 & Stover et al. \\
$8515^{\prime}$-CCGTCCTCGCCCTTTCGC-3' 834 & & \\
\hline alkB 2 & & \\
$8825^{\prime}$-CCTGGCTGGTGATCAGCG-C $3^{\prime} 151$ & & \\
\hline
\end{tabular}

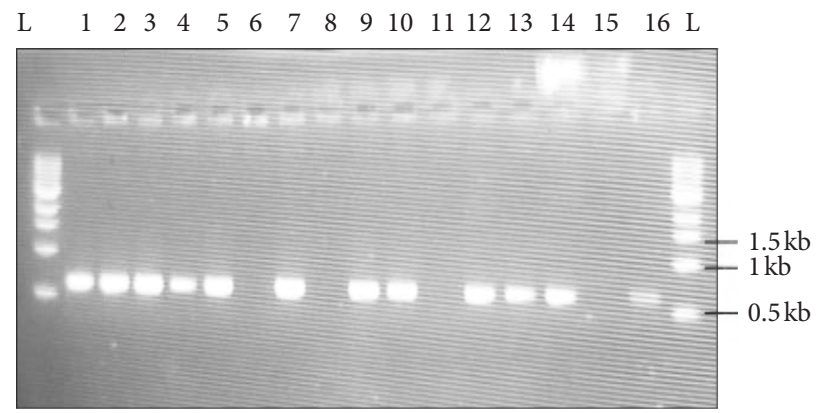

FIGURE 1: PCR products for the amplification of $18 \mathrm{~S}$ rDNA for the fungal isolates $1,2,3,4,5,6,7,8,9,10,11,12,13,14,15$, and 16 using $1200 \mathrm{R}$ and $566 \mathrm{~F}$ universal primers. L represents a $1 \mathrm{~kb}$ ladder. The expected band size amplified is $640 \mathrm{bps}$.

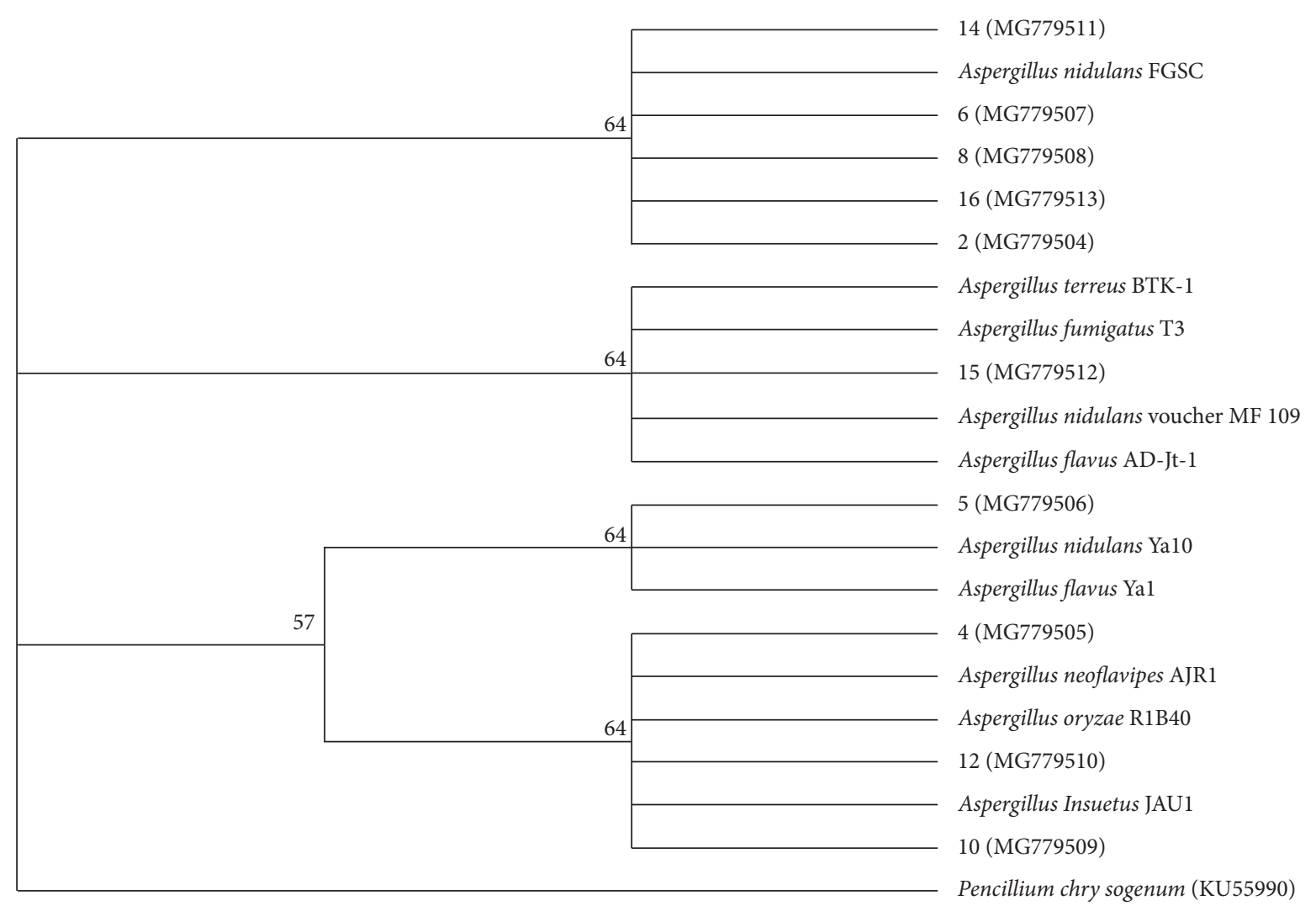

Figure 2: Phylogenetic tree of fungal isolates based on $18 \mathrm{~S}$ rDNA sequences. All screened fungal isolates have NCBI accession codes in brackets. The scale bar refers to 0.007 substitutions per nucleotide position. Bootstrap values obtained with 1000 resampling are referred to as percentages at all branches. 
3.2. Phylogenetic Relatedness of Low-Density Polyethene Degrading Bacterial Isolates. Amplification of bacterial $16 \mathrm{~S}$ rDNA using $1492 \mathrm{R}$ and $8 \mathrm{~F}$ universal primers yielded 1420 bps fragments (Figure 3) which were purified, sequenced, and analyzed. The results were used to obtain accession numbers from the NCBI GenBank. The analyzed sequences were aligned with those of the closest neighbors using ClustaX version 2.1. Phylogenetic relationships were inferred from phylogenetic comparison of the $16 \mathrm{~S}$ rDNA sequences using Mega 7 and maximum-likelihood algorithms to generate the phylogenetic tree (Figure 4) which shows the phylogenetic relationships among the genera and species. Brevibacillus, Bacillus, and Lysinibacillus are in one major clade while Pseudomonas, Ochrobactrum, and Cellulosimicrobium are grouped in another major clade. Bacteria of the genera Bacillus, Brevibacillus, Ochrobactrum, Lysinibacillus, Cellulosimicrobium, and Pseudomonas were identified as effective polyethene degraders. Bacterial isolates A5,1a-Bacillus cereus (MG645256) produced the highest degradation effectiveness in terms of weight loss, i.e., $35.2 \%$, followed by the isolate B2,2-Brevibacillus borstelensis (MG645267) showing 20.28\% from an earlier study [20] while isolates B1,1a-Pseudomonas putida (MG645283) and D4,yn-Brevibacillus borstelensis strain (MG645261) produced a weight loss of $2.88 \%$ and $-6.8 \%$, respectively. The genus Bacillus was most frequently identified among the LDPE biodegrading genera in this study. Species identified under this genus include Bacillus cereus, Bacillus toyonensis, Bacillus thuringiensis, Bacillus subtilis, Bacillus pseudomycoides, Bacillus safensis, and Bacillus niacini. Various studies have been done to investigate the efficacy of genus Bacillus in polyethene degradation, and different species under this genus have been found to have potential to degrade polyethene [24, 25]. Bacillus cereus has been found to be a good bioremediation candidate in the biodegradation of polyethene due to its ability to produce enzymes laccase and manganese peroxidase. In a comparative study, B. cereus was found to be more effective than $B$. sphericus in degrading photo-oxidized and thermos-oxidized LDPE [26]. According to [6], Brevibacillus borstelensis Accession number AY764129 was able to degrade $11 \%$ of nonirradiated polyethene by weight in 30 days. Two bacterial isolates Bacillus amyloliquefaciens (BSM-1) and Bacillus amyloliquefaciens (BSM-2) were isolated from municipal soil and used for polymer degradation studies and were found to produce significant changes on LDPE in terms of weight loss, reduction of tensile strength, and appearance of new functional groups [27]. A novel strain of Pseudomonas, Pseudomonas citronellolis EMBS027, GenBank Accession number KF361478 was isolated by [28] from a municipal landfill in Indore, India, and it degraded $17.8 \%$ of polyethene in 4 days. Different species of Pseudomonas were analyzed for their ability to degrade polyethene and upon incubation for 120 days. Pseudomonas putida resulted in a weight loss of $9 \%$ [29].

3.3. Screening for Enzyme Production. Bacterial isolates were screened for production of enzymes laccase and esterase

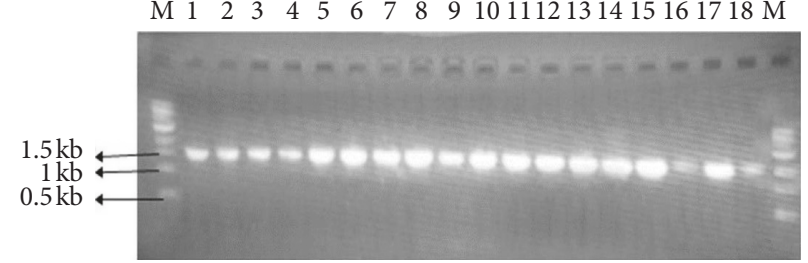

FIgUre 3: Amplification of $16 \mathrm{~S}$ rDNA for the bacterial isolates 1-18 using $1492 \mathrm{R}$ and $8 \mathrm{~F}$ universal primers. $\mathrm{M}$ represents a $1 \mathrm{~kb}$ marker. The expected band size amplified is $1420 \mathrm{bps}$.

(Figure 5) which are among the enzymes implicated in LDPE degradation. Bacterial isolates Brevibacillus borstelensis strain B2,2, Brevibacillus parabrevis strain C2,2a, and Pseudomonas putida strain B1,1 exhibited the highest presence of laccase. Only two isolates Bacillus toyonensis and Bacillus macrolides were negative for laccase activity. Esterase activity was highest in isolates Brevibacillus borstelensis strain D4 yn, Bacillus niacin strain C4,1a, and Pseudomonas putida strain B1,1a. Fungal isolates were screened for production of enzymes laccase and esterase (Figure 6). Isolates B2, 2-Aspergillus fumigatus, A5,1-Aspergillus oryzae, and A4,2a-Aspergillus flavus exhibited the highest levels of laccase enzyme while the highest level of esterase enzyme was attributed to fungi Aspergillus Oryzae.

Production of extracellular enzymes plays an important role in polymer degradation through depolymerization, where the polymer is broken down into smaller subunits [30] which are then enzymatically degraded into intermediary products that can be assimilated into microbial cells [31] and utilized as carbon sources leading to production of energy, water, carbon dioxide, and methane in the case of anaerobic respiration [32]. In this study, production of extracellular enzymes, laccase and esterase, were investigated. Fungal and bacterial isolates in this study were scrutinized for their ability to produce laccase enzyme and isolate B2, 2-Aspergillus fumigatus (MG779513) which had a LDPE degradation effectiveness of $24 \%$ and had the highest diameter of coloration due to laccase production. This could be attributed to its ability to produce higher amounts of laccase and other extracellular enzymes which are believed to play a role in polyethene degradation. According to [33], the production of this enzyme increases when the microbes are in close proximity with the polyethene. Reference [34] was able to extract the crude laccase enzyme which was incubated with polyethene and led to degradation as was evidenced through weight loss, FTIR, and SEM. Esterases catalyze the cleavage of ester bonds [35] of short-chain triglycerides or esters. Esters have been identified as part of the intermediary products produced during polyethene degradation when the postincubation culture media are subjected to GC-MS analysis that can be assimilated into the microbial cells, undergoes hydrolysis to give rise to the subsequent carboxylic acid and alcohol that ultimately undergo respiration to produce energy [36]. Isolate A5,1Aspergillus oryzae (MG779508) with a weight loss of $36.4 \%$ had a high activity of enzyme esterase of $10 \%$. This could have contributed to its high degradation potential compared to other fungal isolates which had lower degradation. 


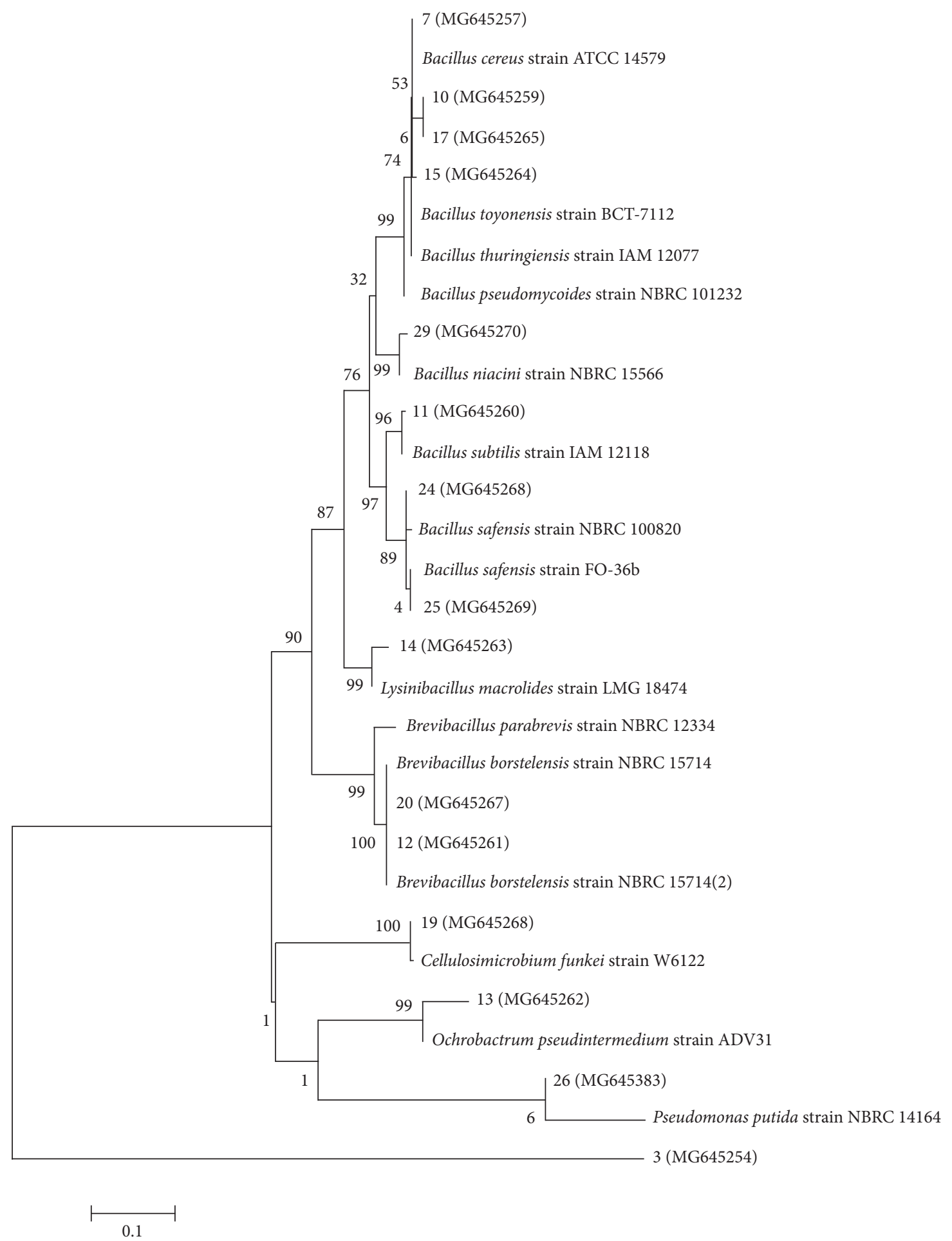

FIGURE 4: Phylogenetic tree generated by MEGA 7 for $16 \mathrm{~S}$ rDNA sequences of the bacterial isolates found to be effective bacterial degraders. All screened bacterial isolates have NCBI accession codes in brackets. The scale bar refers to 0.02 substitutions per nucleotide position. Bootstrap values obtained with 1000 resamplings are referred to as percentages at all branches.

3.4. Screening for AlkB Genes Producing Alkane-Degrading Enzymes. PCR to amplify AlkB genes was done using three sets of AlkB primers. Only one set of the AlkB primer was able to amplify the AlkB gene producing a fragment of size 870 bps. AlkB genes are responsible for production hydrolase enzymes which are responsible for alkane degradation.
The gene was amplified in 4 bacterial samples (Figure 7). A common feature of many alkane degraders is that they contain multiple alkane hydroxylases with overlapping substrate ranges [37]. AlkB- and alkB-related genes code for an alkane-degrading enzyme, alkane hydroxylase [38]. The analysis of the bacterial samples revealed presence of AlkB 1 


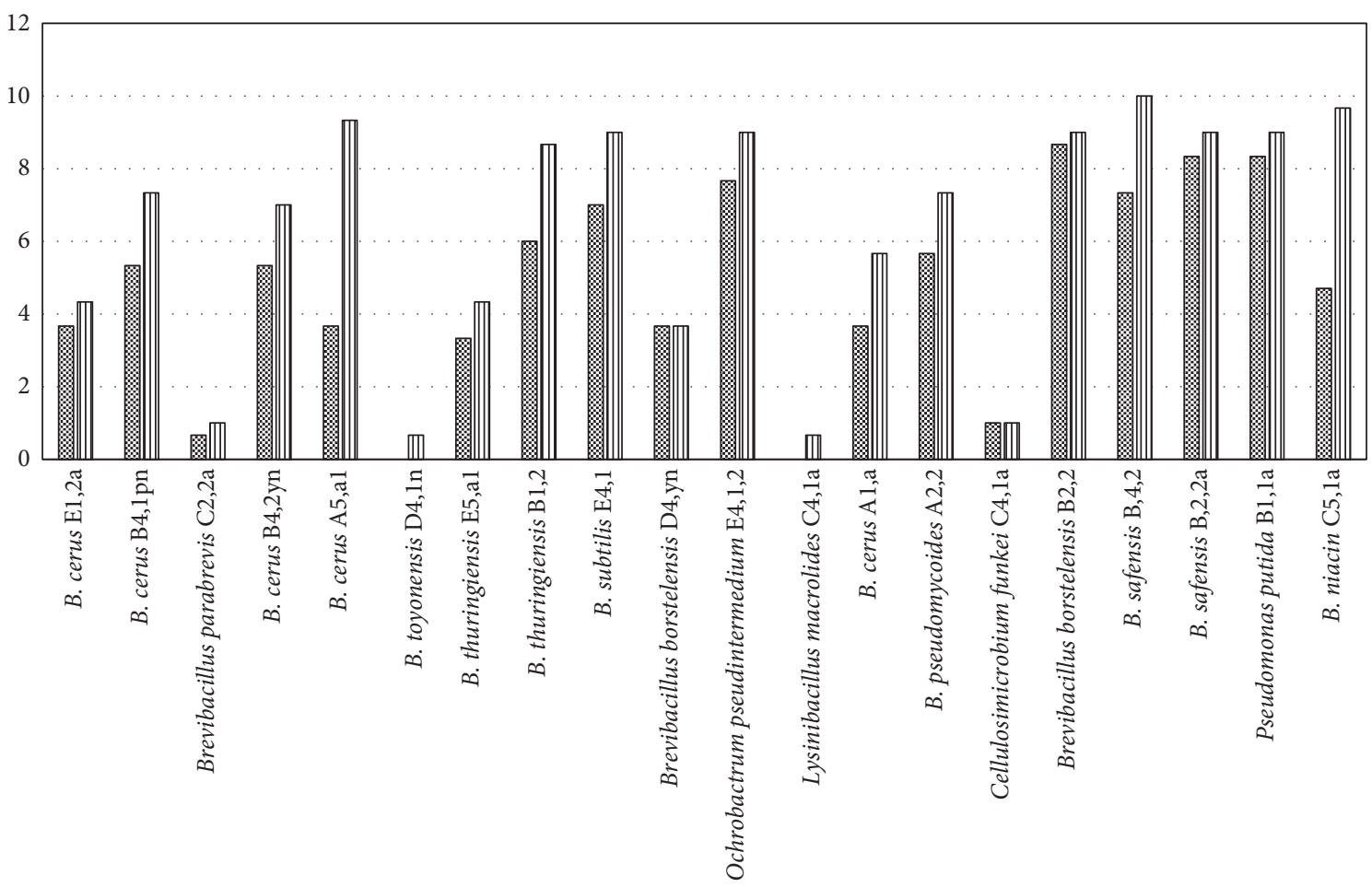

圈 Laccases

孟 Esterases

Figure 5: Presence of enzymes laccase and esterase among the bacterial isolates. Growth of bacterial isolates was measured as colony diameter (mm). Means were grouped using Tukey's honest significant difference test at $P<0.05$.

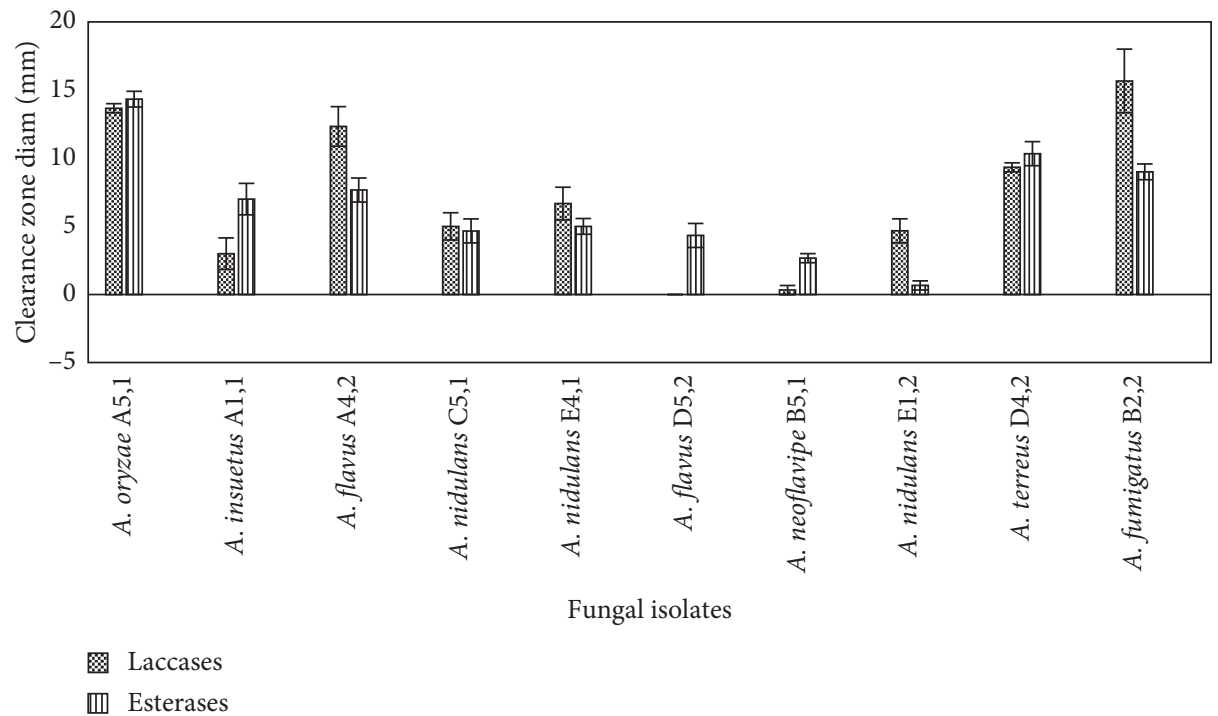

Figure 6: Presence of enzymes laccase and esterase among the fungal isolates. Growth of fungal isolates was measured as colony diameter $(\mathrm{mm})$. Means were grouped using Tukey's honest significant difference test at $P<0.05$.

gene in 4 of the bacterial samples. Bacterial isolates that were positive for alkB 1 gene were D4 yn-Brevibacillus borstelensis, B1,1-Pseudomonas putida, and A5,a1-Bacillus cereus. Alkane biodegradation is initiated through terminal oxidation to the corresponding primary alcohol, which is further oxidized by dehydrogenases to fatty acids which can enter the TCA cycle [39]. This genetic information is an indication of the genetic ability of the microorganisms to degrade long-chain alkanes through production of this enzyme.

3.5. Effect of Temperature on Growth of Fungal Isolates. The growth of fungi at different temperatures $\left(20^{\circ} \mathrm{C}, 30^{\circ} \mathrm{C}\right.$, and $40^{\circ} \mathrm{C}$ ) as shown (Figure 8) revealed that growth at $30^{\circ} \mathrm{C}$ 


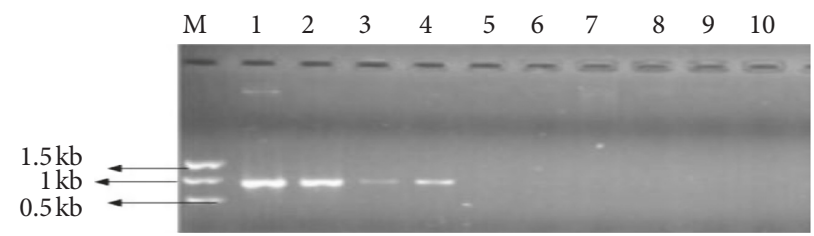

FIGURE 7: PCR products for the amplification of Alkb for the bacterial isolates 1, 2, 3, 4, 5, 6, 7, 8, 9, and 10 using AlkB 1 set 1 primers. Lane 1 represents a $1 \mathrm{~kb}$ ladder. The expected band size amplified is $870 \mathrm{bps}$.

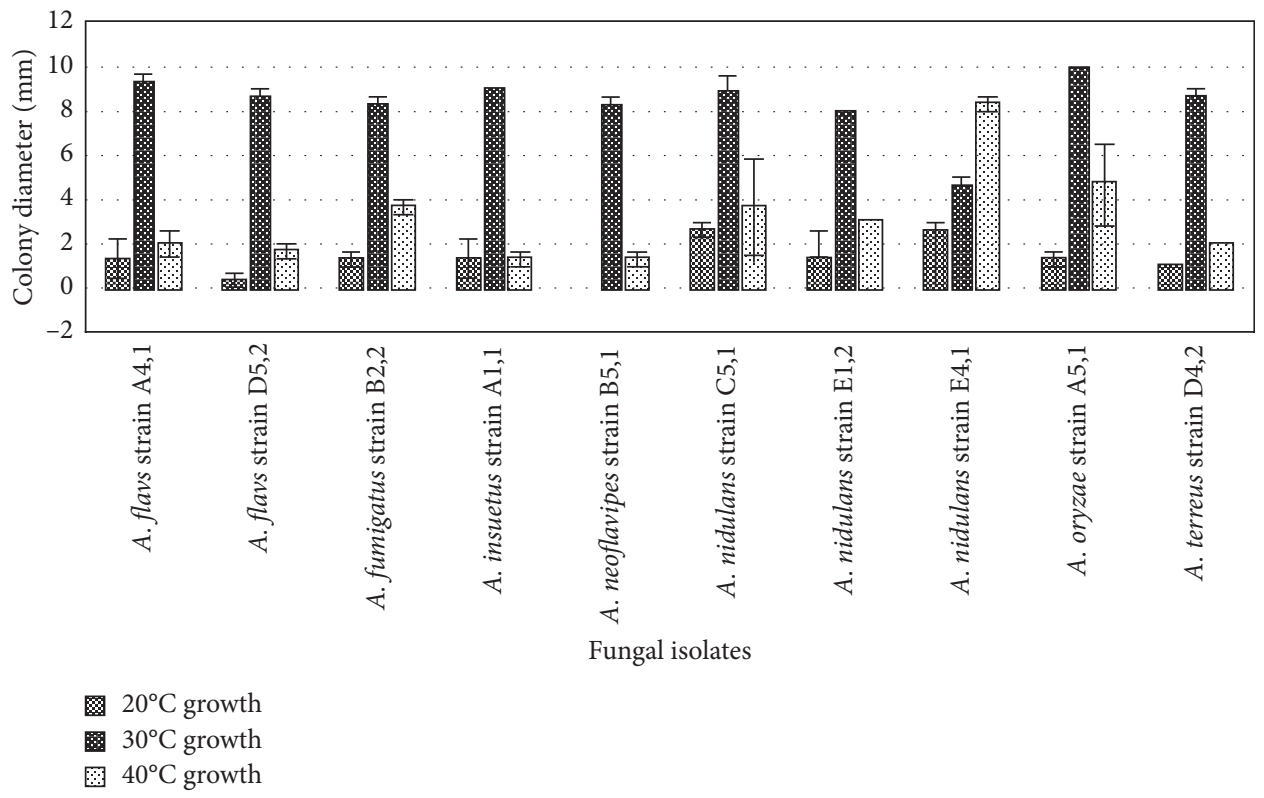

Figure 8: Growth of fungal isolates at $20^{\circ} \mathrm{C}, 30^{\circ} \mathrm{C}$, and $40^{\circ} \mathrm{C}$, respectively.

was significantly higher than growth at $20^{\circ} \mathrm{C}$ and $40^{\circ} \mathrm{C}$ with $A$. oryzae strain A5,1 having the highest growth $(10 \pm 0)$. However, isolate $\mathrm{E} 4,1-A$. nidulans grew optimally at $40^{\circ} \mathrm{C}$. This could be attributed to the fact that the sampling site for these bacteria was from a dumpsite where the temperatures were generally ambient and hence favoring the growth of mesophilic microbes. Laccase production by fungi is influenced by type and concentration of carbon sources, $\mathrm{pH}$, and temperature.

\section{Conclusion}

The present work indicates that soil bacteria and fungi isolated from the dumpsite have potential of degrading polyethene. This is the first study on the isolation of local bacteria and fungi that can degrade LDPE which is the most common plastic in Kenya. Particularly, the application of Aspergillus oryzae strain A5,1 and Bacillus cereus strain A5,a will be beneficial in the bioremediation of polyethene as they exhibited significant degradation effectiveness. It was ascertained that the microorganisms are capable of producing enzymes laccase and esterase which have been confirmed to play a role in degradation of polyethene. The isolates possess the alkane hydroxylase-producing gene $(A l k B)$ which is the molecular explanation for the degradation of LDPE under investigation. Fungi in this study were found to grow optimally at the temperature of $30^{\circ} \mathrm{C}$.

\section{Data Availability}

The data (Figures 1-8 and Table 1) used to support the findings of this study are included within the article.

\section{Conflicts of Interest}

The authors declare that they have no conflicts of interest.

\section{Acknowledgments}

This work has been fully funded by the African Union Commission through the Pan African University Institute of Science, Technology, and Innovation. We highly appreciate the support we got from honest colleagues, Dr. Johnstone Neondo, Dr. Eliud Wafula, Steve Ogada, and Baba Ngom, who gave us sincere and constructive criticism that helped to shape up this final product. We thank the staff and management of the Institute of Biotechnology Research (IBR), Prof. A. B. Nyende, Richard Rotich, Catherine Eyiinda, and Grace Mungai, for providing an enabling environment for laboratory and research work for this study. 


\section{References}

[1] B. Nowak, J. Pajak, M. Drozd-Bratkowicz, and G. Rymarz, "Microorganisms participating in the biodegradation of modified poly-ethene films in different soils under laboratory conditions," International Biodeterioration and Biodegradation, vol. 65, no. 6, pp. 757-767, 2011.

[2] M. C. Aurah, "Assessment of extent to which plastic bag waste management methods used in Nairobi city promote sustainability," American Journal of Environmental Protection, vol. 1, no. 4, pp. 96-101, 2013.

[3] J. P. Eubeler, M. Bernhard, S. Zok, T. P. Knepper, and T. P. Knepper, "Environmental biodegradation of synthetic polymers I. Test methodologies and procedures," Trends in Analytical Chemistry, vol. 28, no. 9, pp. 1057-1072, 2009.

[4] J. D. Gu, "Microbiological deterioration and degradation of synthetic polymeric materials: recent research advances," International Biodeterioration and Biodegradation, vol. 52, no. 2, pp. 69-91, 2003.

[5] R. Pramilla and V. Ramesh, "Potential biodegradation of low density poly-ethene (LDPE) by Acinetobacter baumannii," African Journal of Bacteriology Research, vol. 3, no. 1, pp. 92-95, 2015.

[6] D. Hadad, S. Geresh, and A. Sivan, "Biodegradation of polyethene by the thermophilic bacterium Brevibacillus borstelensis," Journal of Applied Microbiology, vol. 98, no. 5, pp. 1093-1100, 2005.

[7] S. Nanda and S. S. Sahu, "Biodegradability of poly-ethene by Brevibacillus , Pseudomonas, and rhodococcus spp.," New York Science Journal, vol. 3, no. 7, pp. 95-98, 2010.

[8] N. Lucas, C. Bienaime, C. Belloy, M. Queneudec, F. Silvestre, and J. Nava-saucedo, "Chemosphere Polymer biodegradation: mechanisms and estimation techniques," Chemosphere, vol. 73, no. 4, pp. 429-442, 2008.

[9] F. M. Ausubel, R. Brent, R. E. Kingston et al., "Current protocols in molecular biology," Molecular Biology, vol. 1, p. 146, 2003.

[10] W. G. Weisburg, S. M. Barns, D. A. Pelletier, and D. J. Lane, "16S ribosomal DNA amplification for phylogenetic study," Journal of Bacteriology, vol. 173, no. 2, pp. 697-703, 1991.

[11] S. Kumar, G. Stecher, and K. Tamura, "MEGA7: molecular evolutionary genetics analysis version 7.0 for bigger datasets," Molecular Biology and Evolution, vol. 33, no. 7, pp. 1870-1874, 2016.

[12] B. G. Hall, "Building phylogenetic trees from molecular data with MEGA," Molecular Biology and Evolution, vol. 30, no. 5, pp. 1229-1235, 2013.

[13] N. Abdennadher and R. Boesch, "Deploying PHYLIP phylogenetic package on a large scale distributed system," in Proceedings of Seventh IEEE International Symposium on Cluster Computing and the Grid, CCGrid 2007, pp. 673-678, Rio De Janeiro, Brazil, May 2007.

[14] I. Gontia-mishra, N. Tripathi, and S. Tiwari, "A simple and rapid DNA extraction protocol for filamentous fungi efficient for molecular studies," Indian Journal of Biotechnology, vol. 13, pp. 536-539, 2014.

[15] K. Hadziavdic, K. Lekang, A. Lanzen, I. Jonassen, E. M. Thompson, and C. Troedsson, "Characterization of the 18s rRNA gene for designing universal eukaryote specific primers," PLoS One, vol. 9, no. 2, Article ID e87624, 2014.

[16] A. Nayarisseri, M. Yadav, M. Bhatia et al., "Impact of nextgeneration whole-exome sequencing in molecular diagnostics," Drug Invention Today, vol. 5, no. 4, pp. 327-334, 2013.
[17] C. W. James Cappuccino, Microbiology Alaboratory Manual (Eleventh), Pearson Education Limited, San Francisco, CA, USA, 1988.

[18] A. Belhaj, N. Desnoues, and C. Elmerich, "Alkane biodegradation in Pseudomonas aeruginosa strains isolated from a polluted zone: identification of alkB and alkB-related genes," Research in Microbiology, vol. 153, no. 6, pp. 339-344, 2002.

[19] A. Vomberg and U. Klinner, "Distribution of alkB genes within n-alkane-degrading bacteria," Journal of Applied Microbiology, vol. 89, no. 2, pp. 339-348, 2000.

[20] C. N. Muhonja, H. Makonde, G. Magoma, and M. Imbuga, "Biodegradability of polyethylene by bacteria and fungi from Dandora dumpsite Nairobi-Kenya," PLoS One, vol. 13, no. 7, Article ID e0198446, 2018.

[21] A. Indumathi, T. Gayathri, E. Biotechnology, T. Nadu, and T. Nadu, "Plastic Degrading ability of Aspergillus oryzae isolated from the garbage dumping sites of Thanjavur, India," International Journal of Current Microbiology and Applied Sciences, vol. 3, no. 3, pp. 8-13, 2016.

[22] S. Zahra, S. S. Abbas, M. T. Mahsa, and N. Mohsen, "Biodegradation of low-density poly-ethene (LDPE) by isolated fungi in solid waste medium," Waste Management, vol. 30, no. 3, pp. 396-401, 2010.

[23] N. Ojha, N. Pradhan, S. Singh et al., "Evaluation of HDPE and LDPE degradation by fungus, implemented by statistical optimization," Scientific Reports, vol. 7, no. 1, 2017.

[24] P. P. Vimala and L. Mathew, "Biodegradation of polyethene using Bacillus subtilis," Procedia Technology, vol. 24, pp. 232-239, 2016.

[25] K. Harshvardhan and B. Jha, "Biodegradation of low-density poly-ethene by marine bacteria from pelagic waters, Arabian Sea, India," Marine Pollution Bulletin, vol. 77, no. 1-2, pp. 100-106, 2013.

[26] B. Suresh, S. Maruthamuthu, N. Palanisamy, R. Ragunathan, and K. Navaneetha Pandiyaraj, "Investigation on biodegradability of poly-ethene by Bacillus cereus strain Ma-Su isolated from compost," International Research Journal of Microbiology (IRJM), vol. 2, pp. 292-302, 2011.

[27] M. P. Das and S. Kumar, "An approach to low-density polyethene biodegradation by Bacillus amyloliquefaciens," Biotech, vol. 5, no. 1, pp. 81-86, 2015.

[28] M. Bhatia, A. Girdhar, A. Tiwari, and A. Nayarisseri, "Implications of a novel Pseudomonas species on low density poly-ethene biodegradation: an in vitro to in silico approach," SpringerPlus, vol. 3, no. 1, p. 497, 2014.

[29] B. Myint, K. Ravi, M. K. Sakharkar, C. S. Lim, and K. R. Sakharkar, "Biodegradation of low density poly-ethene (LDPE) by Pseudomonas species," Indian Journal of Microbiology, vol. 52, no. 3, pp. 411-419, 2012.

[30] R.-J. Müller, "Biodegradability of polymers: regulations and methods for testing," Biopolymers Online, vol. 4, pp. 365374, 2005.

[31] L. D. M. Sahadevan, C. S. Misra, and V. Thankamani, "A bird's eye view on bioremediation approaches of heavy metals contaminated soil regimes," Open Access Review Article, vol. 3, no. 1, pp. 1-18, 2013, http://environmentaljournal.org/3-1/ ujert-3-1-2.pdf.

[32] J. D. Hamilton, K. H. Reinert, J. V. Hagan, and W. V. Lord, "Polymers as solid waste in municipal landfills," Journal of the Air and Waste Management Association, vol. 45, no. 4, pp. 247-251, 2014.

[33] E. M. El-morsy and E. Ahmed, "Biodegradative activities of fungal isolates from plastic contaminated soils," Mycosphere, vol. 8, no. 8, pp. 1071-1086, 2017. 
[34] H. V. Sowmya, M. Ramalingappa, and B. T. Krishnappa, "Degradation of poly-ethene by Trichoderma harzianumSEM, FTIR, and NMR analyses Degradation of poly-ethene by Trichoderma," Environmental Monitoring and Assessment, vol. 186, no. 10, 2014.

[35] H. Zhang, F. Li, H. Chen et al., "Cloning, expression and characterization of a novel esterase from a South China Sea sediment metagenome," Chinese Journal of Oceanology and Limnology, vol. 33, no. 4, pp. 819-827, 2015.

[36] J. Zhang, X. Wang, J. Gong, and Z. Gu, "A study on the biodegradability of poly-ethene terephthalate fiber and diethylene glycol terephthalate," Journal of Applied Polymer Science, vol. 93, no. 3, pp. 1089-1096, 2004.

[37] W. M. Abd El-Rahim, O. A. M. El-Ardy, and F. H. A. Mohammad, "The effect of $\mathrm{pH}$ on bioremediation potential for the removal of direct violet textile dye by Aspergillus Niger," Desalination, vol. 249, no. 3, pp. 1206-1211, 2009.

[38] M. Gyung Yoon, H. Jeong Jeon, and M. Nam Kim, "Biodegradation of poly-ethene by a soil bacterium and AlkB cloned recombinant cell," Journal of Bioremediation and Biodegradation, vol. 3, no. 4, 2012.

[39] Van Beilen, Z. Li, W. A. Duetz, T. H. M. Smits, and B. Witholt, "Diversity of alkane hydroxylase systems in the environment," Oil and Gas Science and Technology, vol. 58, no. 4, pp. 427440, 2003. 


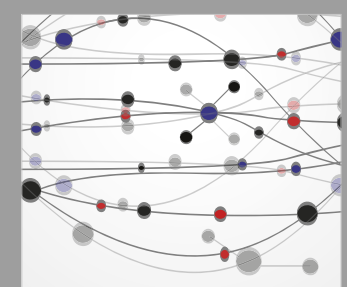

The Scientific World Journal
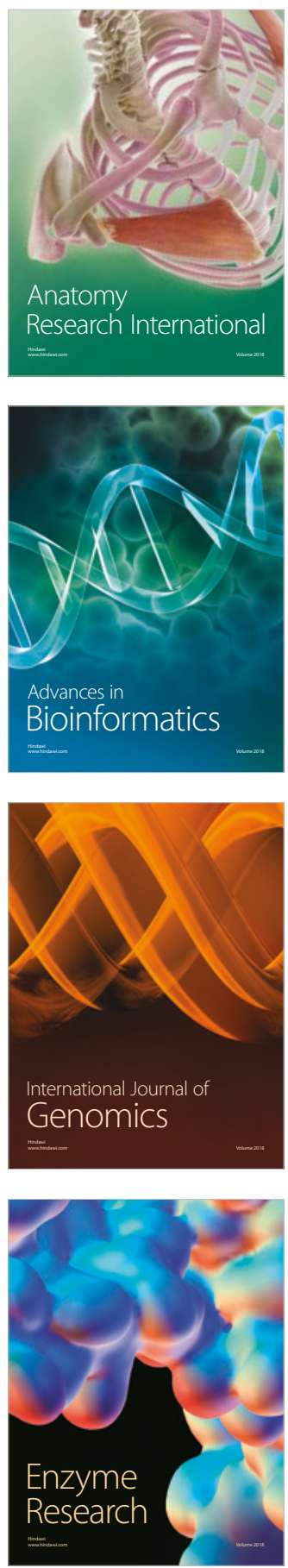
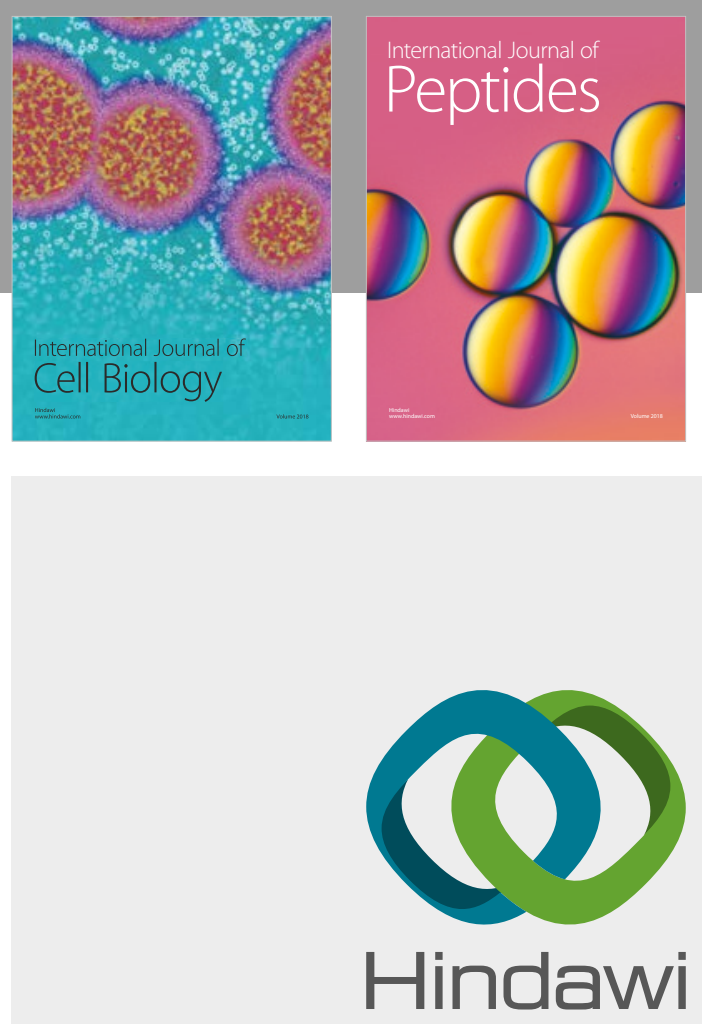

Submit your manuscripts at

www.hindawi.com
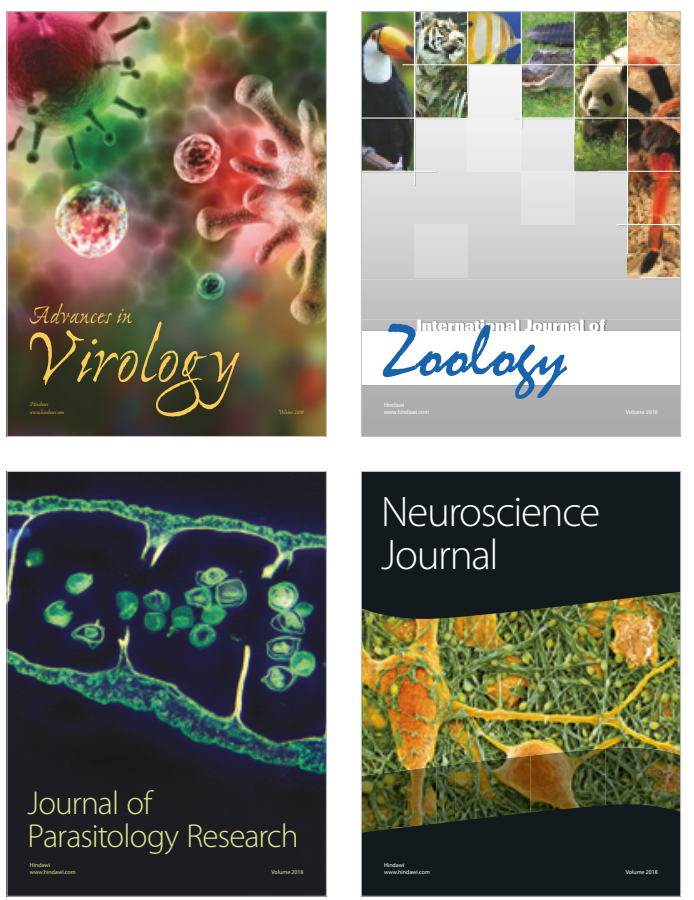
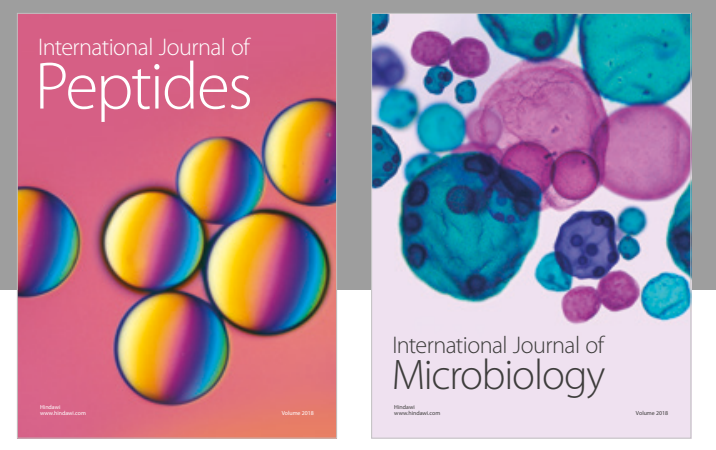

nternational Journal of Microbiology
Journal of
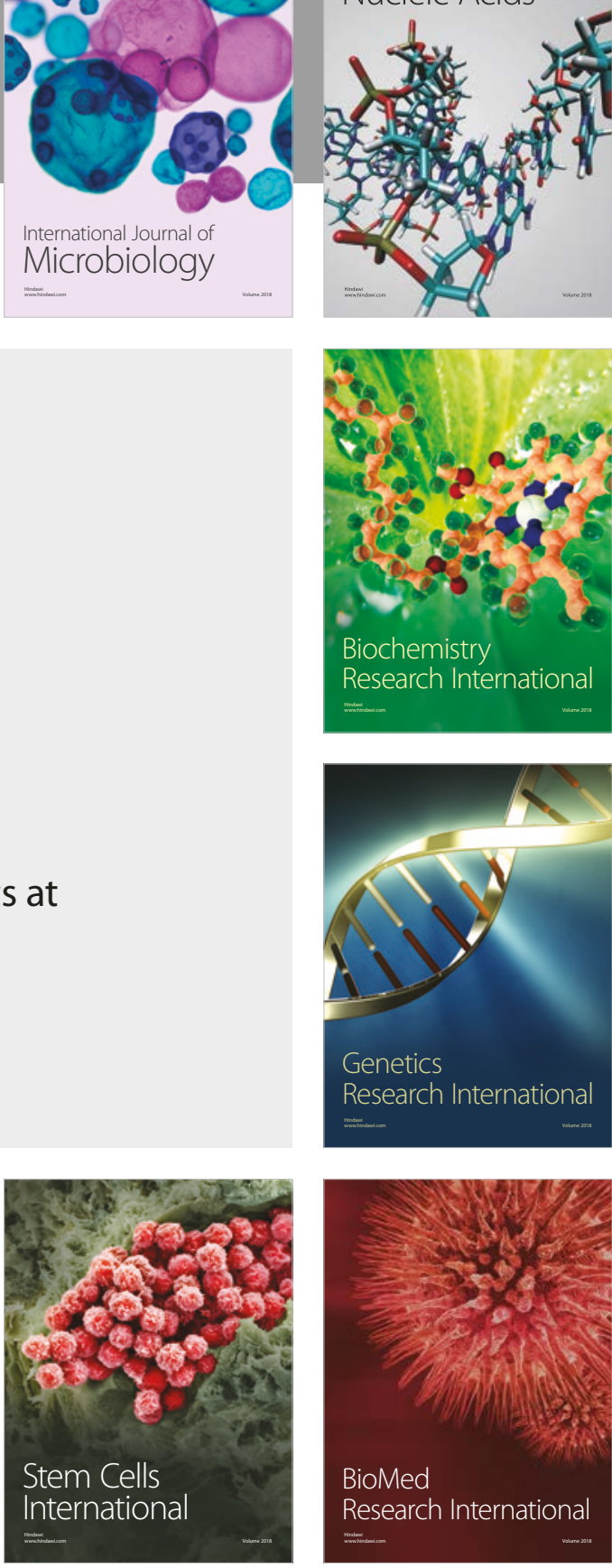
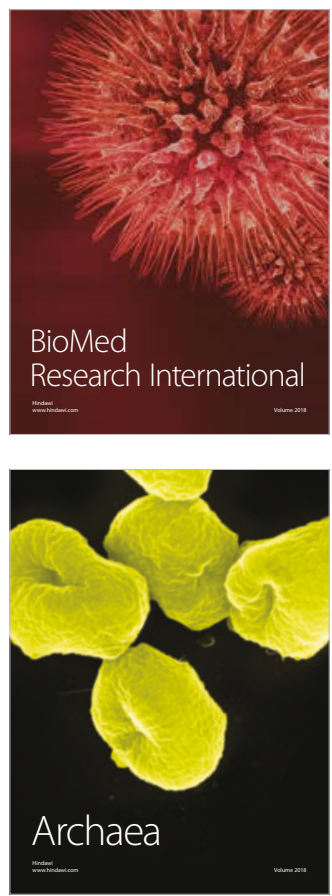